Article

\title{
Responsible Innovation for Sustainable Development Goals in Business: An Agenda for Cooperative Firms
}

\author{
Oier Imaz * (1) and Andoni Eizagirre \\ Faculty of Humanities and Education Sciences, Mondragon Unibertsitatea, 20500 Arrasate, Spain; \\ aeizagirre@mondragon.edu \\ * Correspondence: oimaza@mondragon.edu
}

Received: 30 July 2020; Accepted: 24 August 2020; Published: 26 August 2020

\begin{abstract}
In this contribution, we explore the possibilities of Responsible Innovation (RI) to assess and support the engagement of businesses in the spectrum of Social and Solidarity Economy (SSE) and, in particular, cooperatives to the implementation of Sustainable Development Goals (SDGs) at the firm level. We conduct a critical review of the academic literature on sustainable development and responsible innovation, focusing on the role of business to identify how firms in the spectrum of SSE can contribute through responsible innovation to the sustainable development agenda and how firms in the spectrum of SSE can benefit from it. Results suggest that firms can benefit from responsible innovation in the transformation of their business models. On the other hand, firms in the spectrum of SSE contribute to extending the scope of SDGs to business, not focusing on what cooperatives do by their nature (e.g., principles and values), but their contribution to key horizontal enablers (e.g., partnership and innovation) for the integration of firms in the sustainable development agenda. To our knowledge, this is the first time that the relationship between SSE firms and RI is assessed from the perspective of firms' contribution to SDGs. Further research is needed to sophisticate the translation of particular tools developed in the framework of RI to firms in the spectrum of SSE and, in particular, cooperative firms.
\end{abstract}

Keywords: sustainable development goals; SDGs; responsible research and innovation; RRI; responsible innovation; RI; business; social and solidarity economy; SSE; cooperatives

\section{Introduction}

The contribution of the Social and Solidarity Economy (SSE) for an economy bent towards Sustainable Development Goals (SDG) is widely acknowledged [1-4]. SDGs require a transformative vision based on a 'people-centred and planet-sensitive' economy [5]. This transformation entails addressing root causes of inequality dealing simultaneously with the economic, social, and environmental dimensions of sustainable development, in cluding culture and 'good governance' [6]. To that aim, SDGs make an explicit recognition of the role of business together with governments and civil society [7]. Firms within the spectrum of SSE and, in particular, cooperative firms, are well placed to make a substantial contribution to SDGs and, in particular, their governance agenda.

In general terms, the contribution of the SSE is defended due to a: (i) focus on local territories and vulnerable groups; (ii) capacity to assess structural determinants of exclusion and inequality; and (iii) emphasis on politics of change, meaning active citizenship and participatory democracy [6]. Indeed, cooperative enterprises are considered by nature "a sustainable and participatory form of business" [8]. They are considered capable of advancing more effective, accountable, and transparent business models based on a more inclusive, participatory, and representative decision-making process at different levels [9]. 
However, cooperative firms meet by their very nature not only their capabilities but, also, their particular limits. In general terms, cooperatives find challenging transformation regarding a hostile environment driven by market needs and, also, due to their particularities: democratic ownership, size and innovation, or lack of flexibility to adapt to a permanently changing world [9]. Indeed, change within a cooperative organization follows an incremental rather than a transformative logic, so far as its governance is deeply embedded in the daily practice of its business organization; it evolves in different ways, but radical change seems risky [10].

It might be for these reasons that the contribution of firms in the spectrum of SSE to the transformative agenda boosted by the SDGs tends to be considered in the light of what firms in the spectrum of SSE have by their nature (e.g., principles and values), in stead of what they do for the integration of firms in the implementation of the sustainable development agenda. In our view, this approach limits the potential contribution of firms in the spectrum of SSE to the integration of the private sector in the implementation of the SDGs, as well as the contribution of the SDGs to the transformation of the business models of firms in the spectrum of SSE in the light of it.

To develop this general idea, first, we analyze key features of the 2030 Agenda (Section 3.1) and the opportunities and challenges that partnership with the private sector entails for its implementation (Section 3.2). Innovation, together with the partnership, stands as a key horizontal enabler of sustainable development but requires considering innovation through its contribution to the 2030 Agenda as a whole, not as an objective in itself (Section 3.3). In other words, there is a gap between firms' general commitment to a set of shared goals as the SDGs and concrete actions oriented to their implementation at the level of firms.

To bridge this gap, we turn our attention to responsible innovation and its contribution to the implementation of the European agenda for sustainable development in Europe by 2030 (Section 4.1). We analyze how responsible innovation integrates responsibility and innovation in the attempt of European institutions to orient multiple stakeholders towards the 'grand societal challenges' of our time (Section 4.3). Indeed, responsible innovation provides a framework that, not only calls for partnership, but results in innovation as a process of socio-technical integration among multiple stakeholders (Section 4.2).

On these bases, we contend that responsible innovation provides an appropriate framework to bridge the gap between the orientation of business model innovations towards grand societal challenges at the level of firms and the engagement of the private sector in the implementation of the sustainable development agenda as a whole (Section 5). Moreover, we suggest that it is in this context that the contribution of firms in the spectrum of SSE can be assessed and an agenda established whereby firms in the spectrum of SSE can benefit for the transformation of their business models to an economy bent towards SDGs (Section 6).

\section{Materials and Methods}

In this article, we combine the theoretical-conceptual analysis of two different strands of the literature on 'grand societal challenges' (e.g., sustainable development and responsible innovation) and a critical review on the consideration of the role of the private sector in the implementation of both in their corresponding institutional contexts. On these bases, we aim at outlining an agenda that allows, on one side, the assessment of the contribution of firms in the spectrum of SSE and, in particular, cooperative firms to sustainable development, and, on the other side, the orientation of the transformation of their business models in the same direction.

To establish the departure point for our critical review, we conduct a theoretical-conceptual analysis of official documents (e.g., normative and regulations) issued by relevant institutions to define the conceptual backbone of both agendas: sustainable development and responsible innovation. This departure point is critically assessed in two ways. On one hand, we genealogically revise the evolution of both concepts (e.g., sustainability and innovation) in their corresponding institutional contexts (e.g., United Nations and European Commission). On the other hand, we contrast the results 
of this analysis with official reports issued by relevant institutional bodies in charge of monitoring their implementation (e.g., High-Level Political Forum on Sustainable Development or The Commission's Directorate-General for Research and Innovation).

On these bases, first, we step on the academic literature to contrast the analysis of the conceptual backbone, genealogy, and implementation of both agendas (e.g., sustainable development and responsible innovation) and identify commonalities and differences between them that might shed light on the particular case of the engagement of the private sector in responsible innovation aimed at sustainable development. Second, we step on previous systematic literature reviews on the role of private firms in both sustainable development and responsible innovation, in order to build a better understanding on the reasons that explain the challenges and opportunities for sustainability and innovation in the case of the engagement of the private sector. Finally, the contrast between both strands in the literature on grand societal challenges allows us to outline an agenda for firms in the spectrum of SSE and, in particular, cooperative firms aimed at orienting their contribution to sustainable development through responsible innovation.

\section{Driving Public Policies Towards 'Grand Societal Challenges': the 2030 Agenda}

\subsection{The 2030 Global Agenda for Sustainable Development}

At the global level, the debate on the 'grand societal challenges' is articulated around the Sustainable Development Goals (SDGs) [5]. The SDGs define the commitments agreed among heads of state and government and representatives of the United Nations in 2015 to achieve sustainable development in the economic, social, and environmental dimensions in a balanced and integrated manner by 2030. Specifically, the SDGs establish 17 objectives and 169 goals that seek to stimulate actions to end hunger and provide conditions for the people to live their lives with dignity and equality; protect the planet from its degradation through the sustainable management of natural resources; ensure that the economic, social, and technological progress occurs in harmony with nature; foster peaceful, just, and inclusive societies; and mobilize the necessary means for these ends.

The 2030 Agenda synthesizes a trajectory of more than two decades led by the United Nations department of economic and social affairs and the member states, to build a framework for a global partnership for sustainable development [11]. Compared to its precedents, in particular, the Millennium Development Goals (MDGs) [12], the main innovations of the 2030 Agenda are its universality [13], its scope [14] and integration [15,16], and its governance and call for partnership $[17,18]$.

First, the SDGs promote a global agenda of universal application, while the MDGs introduced a new agenda for development aid focused on the eradication of hunger and extreme poverty. More specifically, the MDGs defined a north-south agenda for development aid focused on overcoming the most extreme consequences of poverty; it required the generosity of rich countries and the commitment of developing countries [19]. In this way, governments and development agencies aspired to reformulate development aid in a context dominated by post-war geopolitics and neoliberal globalization [20]. On the contrary, the SDGs demand effective actions by developing and developed countries. In other words, as expressed by Jeffrey D. Sachs, Ban Ki-moon Special Adviser on the MDGs, "[t]he SDGs should, therefore, pose goals and challenges for all countries-not what the rich should do for the poor, but what all countries together should do for the global wellbeing of this generation and those to come" [13] (p. 2208).

Second, the SDGs extend the scope of the MDGs to the three fundamental pillars of sustainable development: economic development, environmental sustainability, and social inclusion. Criticism about the MDGs underscored that they were made up of a series of measurable indicators that allowed tangible results, but they only addressed the most extreme symptoms of poverty, not its causes [19]. For example, in the debate on the definition of the SDGs, David Griggs and his team suggested that the extension of the MDGs was not enough and that poverty reduction and environmental protection "must be the twin priorities for the SDG," to the extent that environmental 
stability "is a prerequisite for a thriving global society" [14] (p. 305). Hence, the SDGs expand the scope of the MDGs by combining ultimate goals for human development (e.g., education, health, access to essential resources) with the preservation of global commons (e.g., limiting climate change, financial stability, biodiversity) [21].

Third, given the complexity of the challenges, the SDGs refer to the importance of attending to the interlinkages and interdependencies among the different objectives that make up each of the dimensions (e.g., economic, social and environmental) of the 2030 Agenda [5].

The simplicity of the MDGs facilitated practical and specific advances in the fight against poverty by governments and non-government organizations (NGOs) [19]. However, this simplicity limited its scope and impact. SDGs, on the contrary, state the complexity for their implementation due to the universality, in divisibility, and interlinkages between objectives and goals of the sustainable development agenda [16]. The implementation of SGDs, in turn, calls for new governance mechanisms and global partnership among all stakeholders [17]. In particular, SDGs call for a shared effort by governments, the private sector, civil society, United Nations agencies, and other stakeholders [5]. It is for this reason that the SDGs acquire political and instrumental value [15]. They are a benchmark for evaluating human development and can operate as a basis for cooperation and accountability among different stakeholders (political value). In turn, the SDGs are an incentive for cross-sectoral work and to stimulate coherence between the institutions responsible for monitoring and evaluating their development (instrumental value).

\subsection{Two Keys for Implementation (I): Partnership}

SDGs provide an unprecedented framework for partnership between stakeholders and their involvement in the sustainable development agenda's governance, both procedurally and substantively.

Procedurally, as stated by Fukuda-Parr [18], the SDGs "involved an unprecedented level of participation by governments, civil society groups, academics, business groups, and UN agencies, in intense debates in meeting around the world and over the internet" (p. 47). Kharas and Zhang [22], for example, highlight the national, regional, and global thematic consultations, the involvement of managers from 300 of the world's leading companies, the inclusion of the scientific and academic perspectives, the involvement of civil society organizations, or the online survey hold by the United Nations Development Program (UNDP) between 2013 and 2014. On these bases, they defend that the 2030 Agenda restored a trend disrupted by the adoption of the Millennium Goals (MDGs), so far as MDGs were considered "as a product of OECD governments and the international financial institutions" [20] (p. 2044) and the result of a process disconnected "from the consultative and reflective process that set UN development agendas over the 1990s and was monitoring their implementation" [19] (p. 46).

Substantively, on the other hand, the participatory dimension of the SDGs is embodied in SDG-17 with a call to strengthen means of implementation and revitalize global partnership between governments, the private sector, and civil society [23]. Compared to MDGs, "[o]ne of the most significant shifts with development of the SDGs has been the foregrounding of the role of the private sector" [24] (p. 372). Indeed, the explicit reference to the role of firms and their contribution-together with governments and civil society-in SDG-17 is defended as the institution of a new paradigm for sustainable development [7]. The underlying belief is that the advancement of the 2030 Agenda will not be possible "unless governments and many non-government actors mobilize effectively to ensure that they are actually implemented" [16] (p. 912). However, this paradigm change presents an opportunity as well as a challenge for the implementation of the sustainable development agenda.

The involvement of business in the implementation of SDGs is defended as 'a great gift to businesses' so far as the 2030 Agenda represents "the best long term strategic market outlook ever put in front of business" [25] (p. 24). The other way around, the involvement of business in the SDGs is defended as an opportunity due to the potential contribution of the private sector in terms of innovation, responsiveness, efficiency, and the provision of specific skills and resources [24]. Scheyvens et al. [24] underline that this contribution is made explicit both in the academic discourses and international 
regulations so far as NGOs and civil society associations, for example, cannot replace firms in what they do best-meaning, "innovating and delivering market-based solutions" [24] (p. 376).

On the other side, this consideration of the private sector as a social agent comparable, for example, to civil society organizations in the face of public institutions can be problematic. For example, it is usually noticed that corporations interpret SDGs through their contribution to "generating positive publicity, achieving short-term economic goals and satisfying immediate stakeholders" [7] (p. 393). On these bases, Gabrielle Koehler [26] warned that "there is a risk that their presence overrides the progressive trends of not-for-profit NGOs" [26] (p. 747). Indeed, Lou Pingeot [27] analyses in detail the contribution of the private sector to the elaboration of the post-2015 agenda and concludes that it may be problematic due to corporations' focus on growth and technology, a business-oriented vision of development, its orientation to market-driven solutions, or the lack of transparency and control mechanisms in the definition of multi-stakeholder governance.

\subsection{Two Keys for Implementation (II): Innovation}

The definition of the SDGs represents an essential milestone for the orientation of public policies to the 'grand societal challenges' of our time. Accordingly, the SDGs set an agenda for sustainable development whose objectives demand radical transformations. To that end, in novation in science and technology, as well as in the institutions and social practices that constitute it, "has essential roles to play" [28] (p. 10). In other words, in novation critically stands out as a horizontal enabler for the implementation of transformative changes required by the SDGs. However, to play this role innovation needs to be thought in accordance to the universality, scope, and integration and call for a global partnership of the 2030 Agenda.

Regarding the meaning of the concept of innovation, the 2030 Agenda reflects different visions on the meaning of innovation and, consequently, we could identify different interpretations of the role that innovation must play in its implementation.

On one hand, in novation is defined as an objective in itself linked to the construction of resilient infrastructures and the promotion of inclusive and sustainable industrialization [5].

The definition of innovation as an SDG highlights its contribution to the sustainability of the global economic system concerning the use of resources and their impacts (environmental dimension), the support of wellbeing and personal development (social dimension) and the distribution of financial results at the service of human needs (economic dimension) [29]. This objective is specified in indicators such as the industrial employment rate, access to financial services for small and medium-sized enterprises (SMEs), or the expansion of information and communication technologies (ICTs) [30]. Recommendations for the implementation of SDG-9 focus on actions that help overcome inequalities between developed and vulnerable countries, such as facilitating investment to improve connectivity (ICTs), boosting the absorption capacity of technological innovations, or funding SMEs to strengthen the resilience of local infrastructures and economies [31].

On the other hand, in novation, together with science and technology, is defined as a lever or driver that guides the implementation of the sustainable development agenda as a whole.

In this second sense, in novation, together with science and technology, is defined as a means to undertake the disruptive transformations required by the SDGs as a whole, not as an objective in itself [32]. Innovation is not, therefore, only related to SDG-9, "[i]n the SDGs framework, STI features strongly both in Goal 17, as well as a cross-cutting one to achieve several sectoral Goals and Targets" [33] (p. 5). Target 9.5 of SDG-9, to which the quote refers, underscores the role of research and innovation policies as a means of implementation for the 2030 Agenda. This is the reason why experts link innovation to SDG-17; they relate innovation to the implementation of the sustainable development agenda and its call for a global partnership. In other words, research and innovation policies are defined as a collaborative space from which to promote the implementation of the SDGs.

In both cases-innovation as an end and innovation as a mean-innovation stands as a key enabler for sustainable development. However, considering innovation an objective in itself-in close 
connection to industrial infrastructures and technological development-grounds innovation on a technological narrative that assimilates innovation to technology and development to the transfer of technology.

The executive summary of the president of the High-Level Political Forum for Sustainable Development (HLPF) [31], in the section dedicated to SDG-9, highlights the transfer of technology, in support to developing countries, as a means for an equitable sharing of the benefits of innovation, as well as the importance of technology transfer to find solutions to the unequal distribution of resources such as food, energy, or water. On the contrary, the definition of innovation as a means for the implementation of the SDGs as whole underscores the socio-technical nature of the transformations required for the implementation of the SDGs [34]. From this perspective, in novation involves the transformation of backbone systems of modern societies (e.g., energy, mobility, food, water, healthcare, communication) [35]. In the literature, we find references to the 3 Ds model [36], transformative innovation [28], responsible research and innovation [35], open innovation [2], social innovation [37], or challenge- or mission-oriented innovation [38].

These proposals underline the socio-technical nature of innovative transformations and, in our view, more closely reflect the universality, scope, and integration and complexity of the 2030 Agenda.

On one hand, in novation as socio-technical transformation responds adequately to the universality and integrality of the SDGs, challenging unitary conceptions about the directionality of technological change.

From the perspective of innovation, this implies a pluralistic conception of the different possible trajectories to knowledge, in novation, and development displacing the unitary conception of progress that underlies a univocal and unidirectional vision of technological change [36]. The challenge is acknowledging the diversity of trajectories to knowledge, in novation, and development without losing sight on the integral nature of the SDGs [15]. For example, Schot and Steinmueller [35] explain that focusing technological innovations on battery development might allow the renewal of the mobile fleet by electric vehicles. Nevertheless, this technological transformation of the automobile industry does not contribute to sustainable development if it does not come along with the emergence of a new mobility system: promotion of public transport, shared cars, bicycling, etc. To sum up, "[s]ociotechnical system transformation is very different from just developing new radical technological solutions" [35] (p. 1562).

On the other hand, in novation as socio-technical transformation requires new global partnerships and the involvement of all stakeholders in governance, in line with the unprecedented call for a global partnership that features the 2030 Agenda.

The recognition of the diversity of trajectories from innovation to sustainable development underscores the importance of a shared vision. A shared vision compatible with a plurality of trajectories requires, for example, considering the unequal distribution of resources and their consequences; in other words, who wins and who loses [28]. However, more importantly, the diversity of trajectories from innovation to sustainable development requires a shared vision capable of orienting both winners and losers. The SDGs can fulfil this function [39]. However, to this end, the involvement of all stakeholders is necessary. In other words, besides radical technological change, in novation-as socio-technical transformation-for sustainable development "calls for an unprecedented collaboration," because "[i]t is part of an enabling governance environment that STI policies are fully integrated into overarching and sectoral strategies and policies" [33] (p. 15).

\section{Driving Public Policies Towards ‘Grand Societal Challenges': Horizon 2020}

\subsection{Towards a Sustainable Europe by 2030}

In the European context, the European Commission's strategy for sustainable development is specified in the proposal Towards a Sustainable Europe by 2030 [40]. The document is a contribution advanced by the Commission in the context of the debate on the White Paper on the Future of Europe, 
started in 2017. It focuses on the potential of the SDGs as a 'compass' to identify the key enabling factors for sustainable development in Europe. The document establishes two general lines of action: thematic areas (e.g., circular economy, food system, clean energy, and inclusion and social cohesion) and horizontal enabling conditions (e.g., education, science, technology, research and innovation; financing, prices, taxation and competition; conduct responsible for business, corporate social responsibility and new business models; open trade regulation and governance). In other words, in novation, partnership, and governance are considered by the European Commission as 'key horizontal enablers' for the implementation of the SDGs.

About innovation, the document states that "[e]ducation, science, technology, research and innovation are a prerequisite for achieving a sustainable EU economy meeting the SDGs" [40] (pp. 22-23). In particular, at the EU level, the document specifies that "the framework programs for Research and Innovation are a catalyst for sustainable competitiveness, growth and investment" [40] (p. 23). Regarding governance, for its part, the proposal underscores the need for coherence between policies, sectors, and the different levels of decision-making to tackle the interlinkages between challenges and opportunities. Finally, it underscores the importance of partnership with business, pointing out the need for incentives and underlining the potential contribution of the collaborative economy and the social economy.

Concerning the engagement of the private sector in the governance of the agenda for sustainable development, it requires that public institutions, private firms, and civil society explore new models of governance [17]. For example, at the European level, the contribution of the SDG Multiple-Stakeholder Platform [41] to the debate on the European Commission's proposal Towards a sustainable Europe by 2030 [40] underscores the need for greater courage "to explore new and unprecedented partnerships in order to transform governance and business models" [41] (p. 6). To this end, it invites the European institutions to reshape their governance by showing their leadership in the implementation of the 2030 Agenda, creating 'enabling environments' for multi-level governance, exploring new avenues for collaboration with stakeholders, and ensuring cross-sectoral coherence.

On the side of European institutions, the document considers that this course is a 'natural' development of the Europe 2020 strategy [42], and it takes the ten priorities of The Junker Commission [43] as its antecedent to the extent that, according to the Commission, "[k]ey aspects of sustainable development feature in all of the Juncker Commission's 10 priorities" [40] (p. 47). Whether these ten priorities fit such well in the sustainable development agenda can be questioned. The report of the group of experts on the implementation of the sustainable development agenda in the EU [33], for example, in dicates that although the ten priorities of The Juncker Commission can be read from the perspective of the sustainable development agenda, these objectives were not thought in that way. Although, they acknowledge that, on the contrary, "[t]he Horizon 2020 orientation towards societal challenges maps very well onto the set of transformations implied in the new Agenda, across economic, environmental and social dimensions of sustainable development" [33] (p. 20).

This difference, in our view, can be related to the socio-technical dimension of the transformation of innovation that has occurred in the European context; a process that, as we have already explained elsewhere [44-46], culminates in Horizon 2020.

\subsection{Two Keys to Implementation (I): Socio-Technical Integration}

To begin with, it should not be neglected that one of the main metaphors of the historical arrangement concerning research and innovation policies in Europe is the linear model, a model that stimulates a scientific vision of progress and policies based on the impulse of science. Despite the growing practical and empirical evidence, revealed since the 1960s, that refutes it and the progressive replacement of patronage policies by a scientific-technological activity sensitive to market results and its applicative and strategic dimension, throughout the following decades, the investigation policy was guarded of any social interference [47]. In this way, the demarcation between science and society was maintained, based on a sequential and triumphant association between basic research, technological 
application, and countless benefit in the fields of technological security, the natural environment, and social wellbeing [48].

In this sense, new modalities of scientific-technological activity, more permeable to the demands of the social environment, were characterized by a strategic orientation of research and a quasi-exclusive emphasis on technological innovation. Some of the features of this new modality of scientific-technological activity were the expansion of economic criteria in the justification, validation, financing, and evaluation of the expected results, a greater inclination to measure the quality and effectiveness of investment in $I+D$, and a new structure of the R\&D system that encompasses scientific, technological, productive, and financial functions. On this basis, new modalities of scientific-technological activity relegated civil society to the bottom link of commercialization and indicated that integrative socio-technical strategies are fundamentally economistic, and they waterproofed expert R\&D dynamics.

However, this growing openness of the R\&D system to economic stimuli-that precisely shaped science and technology systems between 1980 and 2000—finds substantial limitations to incorporate demands of a social and environmental nature into research and innovation [44].

One of the many ironies of this period can be summed up in this idea: while recognizing the complex nature of the scientific-technological activity, and a more interactive division of labour between different actors in the R\&D system, the diversity of trajectories, by which R\&D can be deployed and progress, is severely neglected. In other words, the opening of scientific-technological activity to the economy shrinks by the same token the space of the possible. This is the reason why the normative properties of the socio-technological trajectory in areas such as energy, transport, agriculture, health, and food have been decided on a limited set of interests and social preferences. In those emerging $R \& D$ patterns, the normative vision of progress was rooted in a set of values, which interact with our ways of knowing, acting, and evaluating, to the point that the direction of innovation is generally taken for granted, as well as it is our predisposition to assume it as an inevitable fact.

However, over the last two decades, the higher permeability of science to the economy and society has been accompanied by new tensions between the opening and closing dynamics that blur the traditional frontiers between science and society. Along these lines, the Fifth Framework Program (1998-2002) and the Sixth Framework Program (2002-2006) gradually unfold an alternative path that is more permeable to open the scope of the issues that can be addressed-transcending the primary economic objective of collaboration and integrating social and ethical aspects. Indeed, this controversial opening-closing process, which anticipates a base tension between clearly instrumental aspirations of the socio-technical integration process and other more substantive ones, has manifested novelties in recent years.

According to the narratives that mobilize programs and their resources, in the Seventh Framework Program (FP7, period 2007-2013), it can be detected a partial reflection of the epistemological and methodological transformations towards a more relational conceptualization (including extra-academic actors) of the process of innovation and to an opening concerning the questions considered debatable (e.g., the social and economic aspects of research and innovation). Moreover, this continuous learning process on the concepts and mechanisms results in the most recent Framework Program Horizon 2020 (period 2014-2020); a framework program advancing this trajectory by claiming responsible research and innovation as one of its transversal axes for the development of a European research and innovation system aimed at tackling the grand societal challenges of our time.

\subsection{Two Keys to Implementation (II): Responsible Innovation}

The Framework Program Horizon 2020 (period 2014-2020) should be understood within this progressive and continuous process of science-society integration, and it states Responsible Research and Innovation (RRI) as a cross-cutting issue of its three main priorities, which are excellent science, in dustrial leadership, and social challenges. More specifically, it is claimed that the RRI approach is formulated to address societal challenges (e.g., global climate change, safe and efficient energy, 
food security, wellbeing and health in the face of demographic transformations, or inclusive and democratic societies) established by Horizon 2020 "building capacities and developing innovative ways of connecting science to society ( ... ). It allows all societal actors (e.g., researchers, citizens, policymakers, business, third sector organizations) to work together during the whole research and innovation process to better align both the process and its outcomes with the values, needs and expectations of European society" [49] (p. 4).

On the other hand, the idea that R\&D policies should be formulated as 'problem solvers' or be pro-active in response to a series of challenges that affect our societies, is beginning to achieve narrative strength. This increased emphasis on the results of scientific-technological activity soon translates into a series of 'grand challenges', which define European research priorities (e.g., health, in clusive and safe society, in dustry, climate, energy and mobility, and food and natural resources). Moreover, to do so, as officially stated in the Lund Declaration (2009), disciplinary research boundaries must be subverted, and collaborative research patterns displaced to social challenges. This comes to suggest that the nature and responsibility of R\&D activities are progressively determined based on their availability and effectiveness to improve realities 'outside' themselves. More specifically, a series of challenges are established that incline and direct the set of trajectories by which scientific-technological research and innovation can be developed and progress.

In this general context, Sutcliffe [50] points out that "RRI is about trying to get better in anticipating problems, taking into account wider social, ethical and environmental issues and being able to create flexible and adaptative systems to deal with these unintended consequences. This is sometimes called 'Anticipatory Governance'" (p. 5). Anticipatory governance suggests the importance of overcoming the deterministic language of scientific-technological development policies, and it is characterized by the ability to "manage emerging knowledge-based technologies while such management is still possible" [51] (p. 128). Thus, anticipation also differs from prediction; instead, it incorporates the inclusion of knowledge, values, and demands whose deliberation scrutinizes the social objectives to which scientific-technological research and innovation must offer an answer. As Stilgoe and Guston clarify, "the question is not to ask what emerging technologies can do to help us, but rather to ask the previous question about what we can do, or not, to help emerging technologies" [52] (p. 857).

This new paradigm, which appeals to co-responsibility, or to respond to each other, has the general purpose of radically transforming the way of understanding and doing science and its relationship with society. In a very brief way, the RRI approach contains two general ingredients: on one hand, it suggests the need to integrate a broader set of actors and interactions in the scientific-technological activity-responsibility for the $\mathrm{R}+\mathrm{D}+\mathrm{i}$ process. On the other hand, it points to a willingness to open up to debate the meaning, purpose, and direction of research and innovation, which can be conceived as boosting inclusive policies to integrate innovation with different challenges and social expectations-responsibility before the results and impacts of $R+D+i$ [52].

In this sense, a widely accepted definition of von Schomberg [53] of RRI makes explicit the interactive and collective nature of responsible research and innovation, understood in terms of mutual responsibility between societal actors:

"Responsible Research and Innovation is a transparent, in teractive process by which societal actors and innovators become mutually responsive to each other with a view to the (ethical) acceptability, sustainability and societal desirability of the innovation process and its marketable products (in order to allow a proper embedding of scientific and technological advances in our society)" (p. 63).

This definition synthesizes the main emerging features of RRI [54]: it opens for discussion the broader purposes of scientific-technological activity; it institutionalizes the mechanisms of co-responsibility between different actors; it re-frames responsibility in response to a context in which the distributed nature of knowledge and the growing uncertainty and unpredictability diminish merely formalist and consequentialist principles [55].

From these considerations, the demand for co-responsibility can be understood as the effort to deploy the following four principles interactively among the different societal actors $[51,54,56]$ : 
anticipation, that is, conceiving and considering a wide variety of possible socio-technical scenarios linked to $\mathrm{R}+\mathrm{D}+\mathrm{i}$; reflexivity, namely, rethinking and reconsidering preferences, demands, values and knowledge in light of the formulation of these scenarios; deliberation, that is, opening those visions, preferences, demands, values, and knowledge to processes of collective deliberation; and receptivity, namely, developing effective governance mechanisms that institutionalize the collective, or inclusive, constitution of research and innovation.

Therefore, in some way, RRI simultaneously urges responsible processes and responsible results and impacts. However, these considerations are risky if they do not incorporate self-criticism about the limits, tensions and possibilities of RRI.

First, the actors involved in deliberation have heterogeneous interests and demands, which, to a great extent, elucidate the contours of the negotiation $[57,58]$. In this sense, it is naive to think that a responsible procedure (e.g., open, participatory, in clusive) will automatically contribute to the achievement of previously established objectives (e.g., the 'right impacts' of von Schomberg).

Second, the rules governing deliberation and the objectives to be pursued are subjected to the discussion so that ethical appeals might make the political nature of disputes contingent. Similarly, the reduction of 'right impacts' to a series of previously determined values and the appeal to ethical commitment based on deliberative procedures, together, displace the essential role of disagreement and contestation in generating co-responsibility links between actors involved.

Third, research ethics has other limitations [59], such as a limited practical scope (e.g., codes of conduct and informed consent procedures) and a utilitarian and consequential interpretation of responsibility, maximizing the positive contributions of technology and minimizing possible negative results.

In any case, RRI is a very vague concept that has as its synchronous purposes a broad adherence-hence, in part, it is a generalist ideology — and sufficient concreteness for its reasonable operationalization [60]. The meaning and purpose of RRI manifest as an appeal to proactive governance of innovation that-beyond mitigating the adverse consequences of $R \& D$ and its marketable value-displays the diversity of expectations and capacities to generate plausible and desirable futures [61]; in other words, RRI appeals to shift the focus to the preferences and values that institute R\&D. Besides this, RRI assembles itself with the significance of the 'grand challenges'; it displaces the product and the purpose of research from knowledge and curiosity to societal challenges. Finally, RRI transcends the established roles in scientific research and its relationship with society for the sake of a more open and relational understanding of scientific-technological research and innovation.

\section{The Role of the Private Sector: Responsible Innovation for Sustainable Development.}

The consideration of industrial and innovation policies in the face of grand societal challenges is not new in Europe, and this trend is not unrelated to the sustainable development agenda. Salvia et al. [62], for example, compare regional trends in research related to the SDGs and identify that, at the European level, research on the sustainable development agenda is focused on areas such as education, in dustry, in novation and infrastructure, and sustainable consumption and production. From their analysis, they conclude that "the approach to these goals may indicate the highest priorities of the European region, which already has good results in several goals of 2030 Agenda, but which has a profile of investing in education and innovations to contribute to the general situation observed" [62] (p. 848).

Their review seems to confirm the capacity of Horizon 2020 to guide research towards grand societal challenges. However, the Achilles' heel of the socio-technical integration that culminates with Horizon 2020 — and the transformation of the European innovation system based on the RRI framework-is the integration of the private sector together with policymakers, the scientific community, and civil society actors [63-66]. 
Based on the conceptual and genealogical analysis of the 2030 Agenda, both in the global and European contexts, presented in the previous two sections, we could conclude that the question about the involvement of the private sector points in two directions.

On one hand, the implementation of the 2030 Agenda requires governance mechanisms capable of integrating the vision of the private sector in a balanced manner concerning other stakeholders (e.g., civil society or NGOs). As already stated, SDGs require multiple and multilateral transformations. Innovation and partnership could be an appropriate means for these ends. Moreover, an open conception of innovation could be considered a booster for partnership among different and even contradictory interpretations of the SDGs. On these bases, the involvement of the private sector represents an opportunity for the success of the sustainable development agenda because of the potential contribution of the private sector in terms of innovation, capabilities, and resources. However, it is a challenge, too, due to mistrust on the role corporate interests could play (and have played) in the sustainable development agenda.

On the other hand, the involvement of the private sector in the implementation of the SDGs-along with inclusive governance mechanisms-points to the ability of firms to align their business models about SDGs, for partnership requires trust and building trust requires coherence between a general commitment to shared goals and concrete actions oriented to their implementation.

In this sense, it is widely recognized that the structure of the SDGs implies a higher degree of responsibility for firms than, for example, Corporate Social Responsibility (CSR) so far as "[t]he business of the SDGs will not materialize from a CSR strategy disconnected from the business core" [25] (p. 23). Firms are required to place SDGs at the core of their business models, in stead of reinforcing business success "by additional social and environmental objectives as a form of responsive corporate social responsibility" [1] (p. 74). Although, this might mean, for example, the recognition of the role of firms as the cause of some of the consequences the 2030 Agenda aspires to solve [24]. Indeed, it is noticed that despite not being mandatory, "they [SDGs] will act as de facto regulation [ ... ]" [67] (p. 17).

In the literature, we could find several business model innovations suitable for undertaking the transformations required by the 2030 Agenda at the level of firms [2]. Rath and Siebold [1], for example, talk about 'conscious enterprises' [68] as a suitable model to create shared value and generate transformational changes in firms. Clinton and Whisnant [3], on the other hand, catalogue 20 types of sustainable business model innovations such as the transition to closed-loop production models or cooperative firms. However, it remains unclear how to articulate the transformative vision entailed by the 2030 Agenda regarding both the governance of innovation and the innovation of business models, in the context of a process of socio-technical integration aimed at orienting both public and private sectors.

In the European context, the involvement of the private sector has become, in the last years, a central concern regarding the capacity of responsible innovation to orient multiple stakeholders towards the grand societal challenges of our time. As Nazarko [66] points out, academic production on responsible research and innovation has slowed down in recent years. The uncertain future of RRI in EU framework programs could explain this changing trend [69]. However, Nazarko suggests that "[s]uch developments may herald stagnation in the research work on RRI unless the industry significantly increases its interest and involvement (... )" [66] (p. 3). Indeed, this interest in extending RRI's sphere of influence to the private sector has materialized in the development of different European projects such as RRI-Tools [70], Res-AGorA [71], Responsible Industry [72], or PRISMA [73], projects that fuel a-still incipient-academic debate on this matter.

If we review the academic debate around the translation of RRI to the private sector, the first finding is that RRI has difficulties attracting the attention of the private sector due to the definition of the concept itself, and the distance with which the private sector perceives the discourse on responsible innovation.

Matinuzzi et al. [74], for example, notice that, from the perspective of the private sector, RRI is a fuzzy concept that integrates a wide variety of notions (e.g., anticipation, reflexivity, deliberation) 
that do not have a precise translation in the field of industry. Along similar lines, but in this case, on the concept of responsibility, Schroeder and Iatridis [75] recognize the potential of RRI to advance a framework for the responsible governance of innovation, but, when considering its application to industry, they point out that "[i]t would be inappropriate to reinvent the wheel by devising RRI tools without first determining the potential of widely accepted CR tools" [75] (p. 3). Dreyer et al. [64] interpret this difficulty as a result of RRI defining itself, mainly, through the involvement of policymakers and academics, without taking into account current developments on innovation governance in the private sector.

Moreover, Dreyer et al. [64] suggest that it is necessary to distinguish between research and innovation. Research refers to the generation of new knowledge; hence, it is the responsibility of the scientific community and institutions, and its value is measured in its integrity: generating solid knowledge transparently and reliably. On the other hand, in novation is the translation of research into a business proposition - and is, therefore, the responsibility mainly of the private sector-and it is quantified based on its ability to generate added value (e.g., economic, social or environmental). With these bases, they suggest that the definition of RRI, its pillars (e.g., anticipation, deliberation (inclusion), reflexivity, and responsiveness, or the identification of good practices, should focus on responsible innovation (RI), not in responsible research. Responsible innovation requires enabling ecosystems (e.g., tight regulation, limited barriers to scaling-up, financing for risky innovations); the involvement of stakeholders in the innovation process: exploration, development, and implementation; and aims to generate shared social value through business model innovations.

The second finding is that the debate on the sustainable agenda and responsible innovation coincide when it comes to highlighting the importance of developing environments that facilitate the engagement of the private sector.

Auer and Jarmai [76], for example, analyze from the perspectives of sustainable innovation and eco-innovation the levers and barriers for innovation of small and medium-sized enterprises (SMEs). They identify six factors that influence their engagement in responsible innovation activities: regulatory framework, financing, growth and cost reduction expectations, organizational and management structures, and collaboration with other actors and networks. Among all of them, the regulatory framework is the main factor that facilitates the implementation of RRI. However, they conclude that each of these factors can act as an incentive or barrier depending on the context. In a similar vein, Gurzawska, Mäkinen, and Brey [77] emphasize that the requirements and incentives of public institutions are the fastest and most effective mechanisms to promote RRI in business. However, they underline that those mechanisms should be aligned with the needs of firms; in short, the involvement of firms in the governance of innovation is necessary.

Thirdly, one of RRI's main contributions to the debate on the inclusion of the private sector in the sustainable development agenda is that, unlike CSR, RRI integrates responsibility (e.g., economic, social, and environmental) in innovation, the primary axis of business model's transformations in firms. Therefore, it provides the means to assess the transformation of firm's business models from the perspective of their contribution to responsible innovation and, hence, to a sustainable development aimed at facing grand societal challenges.

On one hand, Garst et al. [78], for example, analyze the organizational motivations of firms to develop responsible innovations. They distinguish between instrumental (e.g., responding to consumer needs, competitiveness, and reputation), moral (e.g., responsibility and awareness of consequences), and relational motives (e.g., expectations about instrumental and moral motivations). They conclude that these motives are complementary; instrumental motivations, for example, can lead to innovations with a social impact that positively reverts to society's moral expectations. Schroeder and Iatridis [79], in the same vein, consider it necessary to differentiate contractual, legal, and moral responsibilities to make the RRI responsibility concept operative within firms. They suggest that RRI's main contribution is its emphasis on the complementarity of the three of corporate responsibility strands (i.e., contractual, 
legal, and moral) and they argue that even though different types of responsibility operate in firms, they should be assessed together in the light of their contribution to responsible innovation pillars [79].

In this sense, a notable difference between the literature on responsible innovation and sustainable development in firms is the value they recognize to CSR tools.

Iatridis and Schroeder [80], for example, defend that corporate responsibility can contribute to the competitiveness of firms (e.g., reputation, market value, attractiveness to employees, reduction of costs and risks, improve operational efficiency) and the sustainable development agenda (e.g., social justice, collaboration, compliance, environmental protection, health, safety). They analyze a series of instruments defined in the framework of CSR (e.g., standards (ISOs), global initiatives (OECD, UN), principles and roadmaps (CERES, GRI)) which they consider useful for the implementation of RRI in business [81]. With these bases, they defend that standards, global initiatives, and principles allow considering the contribution of firms to the four fundamental pillars of RRI (e.g., anticipation, reflexivity, deliberation (inclusiveness), and responsiveness) departing from mechanisms that firms already apply in their strategies [82].

The identification of mechanisms linked to corporate social responsibility and responsible innovation in firms allows, in turn, the elaboration of indicators providing firms with a framework from which to orient their business model innovations responsibly with regards to the wishes, needs, and aspirations of society. Stahl et al. [83], for example, start from the results of Responsible Industry [72] and present a model to assess the maturity levels of firm's business model innovations in the light responsible innovation. On the other hand, van de Poel et al. [84] start from the results of the European project PRISMA [73] and propose a series of Key Performance Indicators (KPIs) to provide corporate social responsibility policies and business strategies with a comprehensive vision on the business models of firms coherent with the framework for responsible innovation [84].

\section{Discussion: SSE, RI, and SDGs}

To summarise, in this contribution, we aimed at exploring the possibilities of Responsible Innovation (RI) to assess and support the engagement of businesses in the spectrum of Social and Solidarity Economy (SSE) and, in particular, cooperatives to the implementation of Sustainable Development Goals (SDGs). To that aim, our departure point has been, however, unconventional; so far we have focused on one characteristic of firms in the spectrum of SSE that tends to be overlooked, particularly, that they are firms. Therefore, we have critically reviewed the literature on sustainable development and responsible innovation focusing on the role of business in order to explain why both failed to capture the interest of firms and to identify promising avenues to overcome this failure.

The main results of this critical review can be summarised as follows:

The definition of the SDGs represents an essential milestone for the orientation of public policies to the 'grand societal challenges' of our time. Nevertheless, their implementation requires transformative changes.

- Innovation critically stands out as a horizontal enabler for the implementation of the sustainable development agenda. However, targeting socio-technical innovation to global challenges requires partnership and novel governance frameworks that directly involve the private sector.

- Moreover, an open conception of innovation could be considered a booster for partnership among different and even contradictory interpretations of the SDGs. However, a partnership requires considering innovation a process of socio-technical integration.

- RRI provides a useful example to understand what it means to advance innovation and partnership in the context of a process of socio-technical integration aimed at responding to grand societal challenges.

- $\quad$ RRI, and its translation to business, namely, responsible innovation (RI), provides an appropriate framework to orient the transformations necessary for the implementation of the SDGs in firms. 
- However, the engagement of business in the sustainable development agenda requires considering not only business from the perspective of the sustainable development agenda, but also the sustainable development agenda from the perspective of firms.

In this final section, we will discuss the implications of these findings for firms in the spectrum of SSE and, in particular, cooperatives.

The contribution of firms in the spectrum of SSE and, in particular, cooperative firms, to the sustainable development agenda, is defended by the very participatory and sustainable nature of this kind of businesses [8]. Cooperatives, for example, are defined by their triple role as economic actors, social groups, and democratic organizations [9]. This triple role allows them to advance the sustainability agenda through their relationship with the local territory and vulnerable groups; their ability to respond to the structural determinants of exclusion, unsustainability, and inequality; and their emphasis on active citizenship and democratic participation [6]. Mozas-Moral [4], for example, highlights that a large part of the SDGs (e.g., SDG-1-6, SDG-8, SDG-10, SDG-17) are in the DNA of firms of the social and solidarity economy, in general, and of cooperatives' DNA in particular.

That is why we tend to consider that firms in the spectrum of SSE are better positioned per se than conventional firms to advance the agenda for sustainable development. In the case of capitalist firms, the ability of the sustainable development agenda to promote transformative changes in their business models has been questioned, for example, about previous experience with corporate social responsibility [24] or the little interest generated by sustainability in the academic debate on the adaptation of business models, for example, in the field of the industry [85]. Similarly, the contribution of capitalist firms to the governance of the sustainability agenda is challenged due to firms' framing (e.g., biased reading, focus on growth, market solutions) or governance models (e.g., lack of transparency, power imbalances, the preponderance of big corporations) [27].

In this contribution, we have identified that enabling environments for partnership among all stakeholders and the innovation of firms' business models are two critical factors for the engagement of the private sector in the 2030 Agenda. In turn, we have argued that responsible innovation contributes to the sustainable development agenda in both directions. It provides firms a framework for partnership aligned with the European agenda for sustainable development, and it integrates responsibility—economic, social, and environmental—in innovation, a critical axis for the transformation of the business model of firms. Therefore, responsible innovation provides a coherent framework to orient both the engagement of the private sector towards SDGs and the transformation of the business model of firms in the same direction.

On these bases, we suggest that responsible innovation could provide SSE firms and, in particular, cooperative firms with a framework to assist, assess, and advance their contribution to the extension of the 2030 Agenda to the private sector.

First, responsible innovation provides SSE firms with a favourable environment by aligning their contribution to sustainable development with the regional strategy for a sustainable Europe by 2030.

The participation in projects financed by European framework programs such as INCLUD-ED [86] or, more recently, the collaboration of the Debagoiena Open Innovation Platform, of which different cooperatives are part, with EIT Climate-KIC sustains the potential benefits of exploring these lines of collaboration for SSE firms. For example, the need to renew the mechanisms for democratic participation in cooperatives [87] is a recurring theme when setting the agenda for the debate on the governance model in worker cooperatives [88]. Contributions by European projects such as GREAT [89], Res-Agora [71], or Responsible Industry [72] or such as those mentioned in the previous section $[65,83,84]$ can provide the cooperatives with the necessary means to carry out the transformations required by SDGs [35].

Moreover, enabling environments could allow cooperative firms to overcome limitations due to intrinsic characteristics of their business models, what is called 'the firm effect.'

The management and innovation capabilities of cooperatives and their relationship to business performance, for example, is a topic of recurring debate regarding cooperative firms $[90,91]$. On the side of management capabilities, the literature highlights difficulties of cooperatives to attract talented 
managers due to salary limitations, their governance model, or the difficulties in adapting to the culture and values of cooperatives for managers trained in conventional firms. Also, SSE firms are mainly small and medium-sized enterprises; hence, they have limited resources that restrict their capacity for innovation [92].

In both cases, operating in environments that help to sustain their management and innovation capabilities reveals to be critical $[90,93]$. Basterretxea et al. [90], for example, suggest that, in the case of Mondragon, a supra-structure with training centers of its own, could facilitate recruitment and the retention of talented managers. In turn, the endowment of shared structures (e.g., technology centers, banking, mutuality, university) and the existence of a sociopolitical environment favourable to the social economy (e.g., fiscal policy, knowledge) facilitate access to the financing necessary for innovation [93]. In other words, a facilitating environment allows overcoming the limitations for performance that depend on the characteristics of firms in the SSE concerning, for example, management and innovation capabilities.

Third, cooperative firms can take advantage of the instruments and mechanisms developed within the framework of responsible innovation to assess their contribution to the sustainable development agenda as firms, and advance the transformations required by the agenda at the core of their business models.

Responsible innovation provides cooperative firms with a framework to assess their contribution to the sustainability agenda as firms-namely, focusing on their contribution to its horizontal enabling factors (e.g., in novation, financing, corporate responsibility, or governance) as firms [40]—instead of the correspondence of their values and principles to the SDGs. In other words, the contribution of SSE to sustainable development is assessed in the light of the contribution of cooperative firms to developing local social capital [94], social innovation and regional change [95], or their role as catalysts of social impact at the international level [96].

The other way around, RI provides cooperative firms with a framework to improve the orientation of their business models towards SDGs. Lubberink et al. [65], for example, link innovation activities in firms, the instruments used for it, and the basic pillars of responsible innovation. Among others, they identify that anticipation translates into the need to understand the context of innovation to improve long-term vision and better alignment in decision-making, for which firms use techniques such as the scenario method, multi-stakeholder conceptualization, or collaborative business modeling. In turn, this link between activities, mechanisms, and pillars allows them to identify areas for improvement regarding the innovation of their business models.

Finally, we should underline certain limitations of this agenda.

First, the outline of the agenda for the implementation of SDGs through responsible innovation in the case of cooperative firms does not assess the particularities of cooperatives in comparison with conventional firms. This limitation results from the main idea of this contribution. However, it might be that in order to make responsible innovation operative in cooperative firms, certain nuances apply and, accordingly, particular inconsistencies affecting the agenda outlined above arise. Therefore, we find further research necessary to sophisticate the translation of concepts and the adaptation of responsible innovation tools to the particular case of cooperative firms.

Second, we have conducted a critical review stepping on previously published systematic literature reviews on sustainable development and responsible innovation in the private sector. Literature reviews in both strands are sufficiently recent and thorough in basing a meaningful critical review in the case of private firms. However, we are not aware of similar works for the case cooperatives and sustainable development. Responsible innovation could provide the basic categories to analyze the contribution of cooperatives to sustainable development in their daily practices of responsibility systematically.

Author Contributions: Theoretical-conceptual review of sustainable development (Section 3), O.I.; theoretical-conceptual review of responsible research and innovation (Section 4), A.E.; critical review of sustainable development (Section 5), O.I./A.E.; original draft preparation, O.I./A.E.; review and editing, O.I./A.E. All authors have read and agreed to the published version of the manuscript. 
Funding: This research was funded by the Department of economic promotion, tourism and rural environment of the Gipuzkoa Provincial Council as part of the project "Gobernantza kooperatiboaren marko berrituaren implementazioa: parte-integrala eta erantzunkidetasunerako ikerketa-ekintza" (Partaidetza-ekosistemak 12/19) developed by the Institute of Cooperative Studies LANKI at Mondragon Unibersity and supported by the Department of Education, Linguistic Policy and Culture of the Basque Government as part of the project "Ciencia para y con la Sociedad. Modelización anticipatoria para la innovación responsible en los nuevos contextos de producción del conocimiento" (IT 1205-19) developed by the research group PRAXIS of the University of the Basque Country.

Acknowledgments: We would like to thank our colleagues at LANKI, PRAXIS, and HUHEZI, and, especially, to the cooperativists that took part in the project.

Conflicts of Interest: The authors declare no conflict of interest.

\section{References}

1. Raith, M.G.; Siebold, N. Building Business Models around Sustainable Development Goals. J. Bus. Models 2018, 6, 71-77.

2. Cordova, M.F.; Celone, A. SDGs and Innovation in the Business Context Literature Review. Sustainability 2019, 11, 7043. [CrossRef]

3. Clinton, L.; Whisnant, R. Business model innovations for sustainability. In Managing Sustainable Business; Lenssen, G.G., Craig-Smith, N., Eds.; Springer: Dordrecht, The Netherlands, 2019; pp. 463-503.

4. Mozas-Moral, A. Contribución de las Cooperativas Agrarias al Cumplimiento de los Objetivos de Desarrollo Sostenible. Especial Referencia al Sector Oleícola; Ciriec-España: Valencia, Spain, 2019; pp. 1-123.

5. UN, GA Transforming Our World: The 2030 Agenda for Sustainable Development; United Nations General Assembly: New York, NY, USA, 2015.

6. Utting, P. Achieving the Sustainable Development Goals Through Social and Solidarity Economy: Incremental versus Transformative Change; Inter-Agency Task Force on Social and Solidarity Economy: Geneva, Italy, 2018.

7. Buhmann, K.; Jonsson, J.; Fisker, M. Do no harm and do more good too: Connecting the SDGs with business and human rights and political CSR theory. Forthcom. Corp. Gov. Int. J. Bus. Soc. 2019, 19, 389-403. [CrossRef]

8. Wanyama, F.O. Cooperatives and the Sustainable Development Goals: A Contribution to the Post-2015 Development Debate; International Labour Organization and International Co-operative Alliance: Brussels, Belgium; Geneve, Switzerland, 2016.

9. Schwettmann, J. The role of cooperatives in achieving the sustainable development goals-the economic dimension. In Proceedings of the A Contribution to the UN DESA Expert Group Meeting and Workshop on Cooperatives the Role of Cooperatives in Sustainable Development for All: Contributions, Challenges and Strategies, Nairobi, Kenya, 8-10 December 2014; International Labour Organization: Geneva, Switzerland, 2014.

10. Birchall, J. The Governance of Large Cooperative Businesses; Co-Operatives: Manchester, UK, 2017.

11. United Nations Department of Economic and Social Affairs. Sustainable Development. Available online: https://sdgs.un.org/goals (accessed on 25 July 2020).

12. UN, GA. Road Map Towards the Implementation of the United Nations Millennium Declaration; United Nations General Assembly: New York, NY, USA, 2001; p. 58.

13. Sachs, J.D. From millennium development goals to sustainable development goals. Lancet 2012, 379, $2206-2211$. [CrossRef]

14. Griggs, D.; Stafford-Smith, M.; Gaffney, O.; Rockström, J.; Öhman, M.C.; Shyamsundar, P.; Steffen, W.; Glaser, G.; Kanie, N.; Noble, I. Sustainable development goals for people and planet. Nature 2013, 495, 305-307. [CrossRef]

15. Le Blanc, D. Towards integration at last? The sustainable development goals as a network of targets. Sustain. Dev. 2015, 23, 176-187. [CrossRef]

16. Stafford-Smith, M.; Griggs, D.; Gaffney, O.; Ullah, F.; Reyers, B.; Kanie, N.; Stigson, B.; Shrivastava, P.; Leach, M.; O'Connell, D. Integration: The key to implementing the Sustainable Development Goals. Sustain. Sci. 2017, 12, 911-919. [CrossRef]

17. Joshi, D.K.; Hughes, B.B.; Sisk, T.D. Improving governance for the post-2015 sustainable development goals: Scenario forecasting the next 50 years. World Dev. 2015, 70, 286-302. [CrossRef]

18. Fukuda-Parr, S. From the Millennium Development Goals to the Sustainable Development Goals: Shifts in purpose, concept, and politics of global goal setting for development. Gend. Dev. 2016, 24, 43-52. [CrossRef] 
19. Nelson, P.J. Human rights, the Millennium Development Goals, and the future of development cooperation. World Dev. 2007, 35, 2041-2055. [CrossRef]

20. Fukuda-Parr, S.; Hulme, D. International norm dynamics and the "end of poverty": Understanding the Millennium Development Goals. Glob. Gov. Rev. Multilater. Int. Organ. 2011, 17, 17-36. [CrossRef]

21. Loewe, M. Post 2015: How to Reconcile the Millennium Development Goals (MDGs) and the Sustainable Development Goals (SDGs)? German Development Institute: Bonn, Germany, 2012.

22. Kharas, H.; Zhang, C. New agenda, new narrative: What happens after 2015? SAIS Rev. Int. Aff. 2014, 34, 25-35. [CrossRef]

23. Maltais, A.; Weitz, N.; Åsa, P. SDG 17: Partenership for the Goals. A Review of Research Needs, Technical Annex to the Formas Report Forskning för Agenda 2030; Stockholm Environment Institute: Stockholm, Sweden, 2018; p. 46.

24. Scheyvens, R.; Banks, G.; Hughes, E. The private sector and the SDGs: The need to move beyond 'business as usual. Sustain. Dev. 2016, 24,371-382. [CrossRef]

25. Pedersen, C.S. The UN sustainable development goals (SDGs) are a great gift to business! Procedia CIRP 2018, 69, 21-24. [CrossRef]

26. Koehler, G. Seven decades of 'development', and now what? J. Int. Dev. 2015, 27, 733-751. [CrossRef]

27. Pingeot, L. Corporate Influence in the Post-2015 Process; Global Policy Forum: Bonn, Germany, 2014.

28. Leach, M.; Rockstrom, J.; Raskin, P.; Scoones, I.; Stirling, A.C.; Smith, A.; Thompson, J.; Millstone, E.; Ely, A.; Arond, E.; et al. Transforming Innovation for Sustainability. Ecol. Soc. 2012, 17, 11. [CrossRef]

29. Nyasimi, M.; Peake, L. Review of Targets for The Sustainable Development Goals: The Science Perspective; International Council of Science and International Social Science Council: Paris, France, 2015; pp. 31-34.

30. HLPF 2017. Thematic Review of SDG-9: Build. Resilient Infrastructure; Promote Inclusive and Sustainable Industry and Foster Innovation; United Nations High-level Political Forum on Sustainable Development: New York, NY, USA, 2017.

31. HLPF 2017. High-Level Political Forum on Sustainable Development; United Nations High-level Political Forum on Sustainable Development: New York, NY, USA, 2017.

32. STI Forum Co-Chair's Summary of the Multi-Stakeholder Forum on Science, Technology and Innovation for the Sustainable Development Goals; United Nations Multi-Stakeholder Forum on Science, Technology and Innovation for the Sustainable Development Goals: New York, NY, USA, 2016.

33. Giovannini, E.; Niestroy, I.; Nilsson, M.; Roure, F.; Spanos, M. The Role of Science, Technology and Innovation Policies to Foster the Implementation of the Sustainable Development Goals; The Commision's Directorate General for Research and Innovation: Luxembourg, 2015.

34. Asiimwe, M.M.; De Kock, I.H. An analysis of the extent to which Industry 4.0 has been considered in sustainability or socio-technical transitions. S. Afr. J. Ind. Eng. 2019, 30, 41-51. [CrossRef]

35. Schot, J.; Steinmueller, W.E. Three frames for innovation policy: R\&D, systems of innovation and transformative change. Res. Policy 2018, 47, 1554-1567. [CrossRef]

36. Stirling, A. Direction, Distribution and Diversity! Pluralizing Progress in Innovation, Sustainability and Development; STEPS Working Papers; STEPS Centre: Brighton, UK, 2009.

37. Eichler, G.M.; Schwarz, E.J. What sustainable development goals do social innovations address? A systematic review and content analysis of social innovation literature. Sustainability 2019, 11, 522. [CrossRef]

38. Mazzucato, M.; Kattel, R.; Ryan-Collins, J. Challenge-Driven Innovation Policy: Towards a New Policy Toolkit. J. Ind. Compet. Trade 2020, 20, 421-437. [CrossRef]

39. Von Geibler, J.; Piwowar, J.; Greven, A. The SDG-Check: Guiding Open Innovation towards Sustainable Development Goals. Technol. Innov. Manag. Rev. 2019, 9, 20-37. [CrossRef]

40. EC. Reflection Paper Towards a Sustainable Europe by 2030; European Commission: Brussels, Belgium, 2019.

41. SDG. Multi-stakeholder Platform Europe Moving Towards a Sustainable Future; The Multi-Stakeholder Platform on the Implementation of the Sustainable Development Goals in the European Union: Brussels, Belgium, 2018.

42. EC. Europe 2020: A Strategy for Smart, Sustainable and Inclusive Growth 2010; European Commission: Brussels, Belgium, 2010.

43. Bassot, E.; Hiller, W. The Juncker Commission's ten priorities: State of play in mid-2016; European Parliament Research Services: Brussels, Belgium, 2016.

44. Eizagirre, A.; Rodríguez, H.; Ibarra, A. Politicizing Responsible Innovation: Responsibility as Inclusive Governance. Int. J. Innov. Stud. 2017, 1, 20-36. [CrossRef] 
45. Imaz, O.; Eizagirre, A.; Ibarra, A. Democratizar los futuros socio-técnicos: Ecologías deliberativas para una gobernanza anticipatoria. In Anticipación e Innovación Responsable. La Construcción de Futuros Alternativos para la Ciencia y la Tecnología; Rodríguez, H., Urueña, S., Eizagirre, A., Imaz, O., Eds.; Biblioteca Nueva: Madrid, Spain, 2020; pp. 197-229.

46. Imaz, O.; Eizagirre, A. Innovar la governanza de la investigación y la innovación: La experimentación de prácticas deliberativas en europa. Caleidoscopio, in press.

47. Sarewitz, D. Frontiers of Illusion: Science, Technology and Politics of Progress; Temple University Press: Philadelphia, PA, USA, 1996; pp. 1-256.

48. Eizagirre, A.E. El discurso sobre las políticas de ciencia y tecnología: Marcos y paradigmas. Argum. Razón Téc. Rev. Esp. Cienc. Tecnol. Soc. Filos. Tecnol. 2015, 18, 39-68.

49. EC. Horizon 2020-Work Programme 2014-2015: 16. Science with and for Society; European Commission: Brussels, Belgium, 2013; p. 75.

50. Sutcliffe, H. A Report on Responsible Research and Innovation; MATTER: Brussels, Belgium, 2011; p. 34.

51. Guston, DH Understanding' anticipatory governance. Soc. Stud. Sci. 2014, 44, 218-242. [CrossRef] [PubMed]

52. Stilgoe, J.; Guston, D.H. Responsible research and innovation. In The Handbook of Science and Technology Studies; Ulrike, F., Fouché, R., Miller, C., Smith-Doerr, L., Eds.; The MIT Press: Cambridge, UK, 2017; pp. 853-880.

53. Von Schomberg, R. A vision of responsible research and innovation. In Responsible Innovation: Managing the Responsible Emergence of Science and Innovation in Society; Owen, R., Bessant, J., Heintz, M., Eds.; John Wiley \& Sons: Chichester, UK, 2013; pp. 51-74.

54. Owen, R.; Stilgoe, J.; Macnaghten, P.; Gorman, M.; Fischer, E.; Guston, D.A. A framework for responsible innovation. In Responsible Innovation: Managing the Responsible Emergence of Science and Innovation in Society; Owen, R., Bessant, J., Heintz, M., Eds.; John Wiley \& Sons: Chichester, UK, 2013; pp. 27-50.

55. Adam, B.; Groves, C. Futures tended: Care and future-oriented responsibility. Bull. Sci. Technol. Soc. 2011, 31, 17-27. [CrossRef]

56. Stilgoe, J.; Owen, R.; Macnaghten, P. Developing a framework for responsible innovation. Res. Policy 2013, 42, 1568-1580. [CrossRef]

57. Van Oudheusden, M. Where are the politics in responsible innovation? European governance, technology assessments, and beyond. J. Responsible Innov. 2014, 1, 67-86. [CrossRef]

58. De Saille, S. Innovating innovation policy: The emergence of 'Responsible Research and Innovation'. J. Responsible Innov. 2015, 2, 152-168. [CrossRef]

59. Rip, A. The Past and Future of RRI. Life Sci. Soc. Policy 2014, 10, 115-133. [CrossRef]

60. Rip, A. The clothes of the emperor. An essay on RRI in and around Brussels. J. Responsible Innov. 2016, 3, 290-304. [CrossRef]

61. Ribeiro, B.E.; Smith, R.D.; Millar, K. A mobilizing concept? Unpacking academic representations of responsible research and innovation. Sci. Eng. Ethics 2017, 23, 81-103. [CrossRef]

62. Salvia, A.L.; Leal Filho, W.; Brandli, L.L.; Griebeler, J.S. Assessing research trends related to Sustainable Development Goals: Local and global issues. J. Clean. Prod. 2019, 208, 841-849. [CrossRef]

63. Scholten, V.E.; Blok, V. Foreword: Responsible innovation in the private sector. J. Chain Netw. Sci. 2015, 15, 101-105. [CrossRef]

64. Dreyer, M.; Chefneux, L.; Goldberg, A.; Von Heimburg, J.; Patrignani, N.; Schofield, M.; Shilling, C. Responsible innovation: A complementary view from industry with proposals for bridging different perspectives. Sustainability 2017, 9, 1719. [CrossRef]

65. Lubberink, R.; Blok, V.; Van Ophem, J.; Omta, O. Lessons for responsible innovation in the business context: A systematic literature review of responsible, social and sustainable innovation practices. Sustainability 2017, 9, 721. [CrossRef]

66. Nazarko, L. Responsible Research and Innovation in Enterprises: Benefits, Barriers and the Problem of Assessment. J. Open Innov. Technol. Mark. Complex. 2020, 6, 12. [CrossRef]

67. Bastida, M.; Vaquero García, A.; Cancelo Márquez, M.; Olveira Blanco, A. Fostering the Sustainable Development Goals from an Ecosystem Conducive to the SE: The Galician's Case. Sustainability 2020, 12, 500. [CrossRef]

68. Pavlovich, K.; Corner, P.D. Conscious enterprise emergence: Shared value creation through expanded conscious awareness. J. Bus. Ethics 2014, 121, 341-351. [CrossRef] 
69. Owen, R.; Pansera, M. Responsible Innovation and Responsible Research and Innovation. In Handbook on Science and Public Policy; Simon, D., Kuhlmann, S., Stamm, J., Canzler, W., Eds.; Edward Elgar Publishing: Cheltenham/Northampton, UK, 2019; pp. 26-49.

70. Groves, C. Review of RRI Tools Project. J. Responsible Innov. 2017, 4, 371-374. [CrossRef]

71. Lindner, R.; Kuhlmann, S.; Randles, S.; Bedsted, B.; Gorgoni, G.; Griessler, E.; Loconto, A.; Mejlgaard, N. Navigating Towards Shared Responsibility in Research and Innovation: Approach, Process and Results of the Res-AGorA Project; Fraunhofer Institute for Systems and Innovation Research: Karlsruhe, Germany, 2016; p. 97.

72. Porcari, A.; Borsella, E.; Mantovani, E.; Stahl, B.; Flick, C.; Ladikas, M.; Hahn, J.; Brem, A.; Yaghmaei, E.; Søraker, J.H. Responsible-Industry: Executive Brief: Implementing Responsible Research and Innovation in ICT for an Ageing Society; Responsible Industry: Roma, Italy, 2016; p. 58.

73. Maia, M.J. RRI in Industry. TATuP-Z. Für Tech. Theor. Prax. 2018, 27, 77-79. [CrossRef]

74. Martinuzzi, A.; Blok, V.; Brem, A.; Stahl, B.; Schönherr, N. Responsible research and innovation in industry-Challenges, in sights and perspectives. Sustainability 2018, 10, 702. [CrossRef]

75. Schroeder, D.; Iatridis, K. Introduction: More Responsible Researchers and Innovators. In Responsible Research and Innovation in Industry; Iatridis, K., Schroeder, D., Eds.; Springer: Cham, Switzerland, 2016; pp. 1-4.

76. Auer, A.; Jarmai, K. Implementing responsible research and innovation practices in SMEs: Insights into drivers and barriers from the Austrian medical device sector. Sustainability 2018, 10, 17. [CrossRef]

77. Gurzawska, A.; Mäkinen, M.; Brey, P. Implementation of Responsible Research and Innovation (RRI) practices in industry: Providing the right incentives. Sustainability 2017, 9, 1759. [CrossRef]

78. Garst, J.; Blok, V.; Jansen, L.; Omta, O.S. Responsibility versus profit: The motives of food firms for healthy product innovation. Sustainability 2017, 9, 2286. [CrossRef]

79. Schroeder, D.; Iatridis, K. The basics of responsible research and innovation. In Responsible Research and Innovation in Industry; Iatridis, K., Schroeder, D., Eds.; Springer: Cham, Switzerland, 2016; pp. 5-30.

80. Iatridis, K.; Schroeder, D. The Basics of Corporate Responsibility. In Responsible Research and Innovation in Industry; Iatridis, K., Schroeder, D., Eds.; Springer: Cham, Switzerland, 2016; pp. 31-38.

81. Iatridis, K.; Schroeder, D. An overview of corporate responsibility tools and their relationship with responsible research and innovation. In Responsible Research and Innovation in Industry; Iatridis, K., Schroeder, D., Eds.; Springer: Cham, Switzerland, 2016; pp. 39-64.

82. Iatridis, K.; Schroeder, D. Applying Corporate Responsibility Tools to Responsible Research and Innovation. In Responsible Research and Innovation in Industry; Iatridis, K., Schroeder, D., Eds.; Springer: Cham, Switzerland, 2016; pp. 65-81.

83. Stahl, B.C.; Obach, M.; Yaghmaei, E.; Ikonen, V.; Chatfield, K.; Brem, A. The Responsible Research and Innovation (RRI) maturity model: Linking theory and practice. Sustainability 2017, 9, 1036. [CrossRef]

84. Van de Poel, I.; Asveld, L.; Flipse, S.; Klaassen, P.; Scholten, V.; Yaghmaei, E. Company strategies for Responsible Research and Innovation (RRI): A conceptual model. Sustainability 2017, 9, 2045. [CrossRef]

85. Kamble, S.S.; Gunasekaran, A.; Gawankar, S.A. Sustainable Industry 4.0 framework: A systematic literature review identifying the current trends and future perspectives. Process. Saf. Environ. Prot. 2018, 117, 408-425. [CrossRef]

86. Flecha, R. European research, social innovation and successful cooperativist actions. Int. J. Qual. Serv. Sci. 2012, 4, 332-344. [CrossRef]

87. Azkarraga, J.; Cheney, G.; Udaondo, A. Workers' participation in a globalized market: Reflections on and from Mondragon. In Alternative Work Organizations; Atzeni, M., Ed.; Pagrave MacMillan: London, UK, 2012; pp. 76-102.

88. Cheney, G.; Santa Cruz, I.; Peredo, A.M.; Nazareno, E. Worker cooperatives as an organizational alternative: Challenges, achievements and promise in business governance and ownership. Organization 2014, 21, 591-603. [CrossRef]

89. Pellé, S.; Reber, B. From Ethical Review to Responsible Research and Innovation; John Wiley \& Sons: London, UK, 2016; Volume 3, pp. 1-206.

90. Basterretxea, I.; Albizu, E. Does training policy help to attract, retain, and develop valuable human resources? Analysis from the Mondragon case. In Advances in the Economic Analysis of Participatory and Labor-Managed Firms; DeVaro, J., Ed.; Emerald Group Publishing Limited: Bingley, UK, 2011; Volume 12, pp. 231-260.

91. Heras-Saizarbitoria, I.; Basterretxea, I. Do co-ops speak the managerial lingua franca? An analysis of the managerial discourse of Mondragon cooperatives. J. Co-Op. Organ. Manag. 2016, 4, 13-21. [CrossRef] 
92. Nieto, M.J.; Santamaría, L. Technological collaboration: Bridging the innovation gap between small and large firms. J. Small Bus. Manag. 2010, 48, 44-69. [CrossRef]

93. Basterretxea, I.; Martínez, R. Impact of management and innovation capabilities on performance: Are cooperatives different? Ann. Public Coop. Econ. 2012, 83, 357-381. [CrossRef]

94. Arando, S.; Gago, M.; Freundlich, F.; Ugarte, L. Capital social y cooperativismo. Proj. Proy. Proj. 2012, 2-3, 41-54. [CrossRef]

95. Gallego-Bono, J.R.; Chaves-Avila, R. How to boost clusters and regional change through cooperative social innovation. Econ. Res.-Ekon. Istraživanja 2019, 1-17. [CrossRef]

96. Bretos, I.; Díaz-Foncea, M.; Marcuello, C. International Expansion of Social Enterprises as a Catalyst for Scaling up Social Impact across Borders. Sustainability 2020, 12, 3262. [CrossRef]

(C) 2020 by the authors. Licensee MDPI, Basel, Switzerland. This article is an open access article distributed under the terms and conditions of the Creative Commons Attribution (CC BY) license (http://creativecommons.org/licenses/by/4.0/). 